\title{
La Ciencia Recreativa and the popularisation of science in Mexico in the 19th century
}

\section{Maria Rachel Fróes da Fonseca}

\begin{abstract}
In the last decades of the 19th century education played a major role in Mexican society, when efforts were being made to restructure it based on the objective teaching of sciences, which was regarded as the driving force behind the change needed in various sectors such as industry and public health. In this context, the so-called science disseminators aimed to communicate their knowledge to the general public, mainly to the working classes and the children. Journalism grew and reached a wide range of themes and audiences. They believed in the idea of a science for all and that sciences were an instrument to know the new nations and educate the population. It is worth mentioning La ciencia recreativa, a publication dedicated to children and working classes. Between 1871 and 1879 it was edited by the topographical engineer and surveyor José Joaquín Arriaga (1831-1896), who aimed to generalise the scientific knowledge of cosmography, mineralogy, meteorology, physics, botany, zoology, descriptive geography and industrial agriculture.
\end{abstract}

\section{Keywords}

History of public communication of science; Science education

Introduction

In Mexico, from the Restored Republic (1867-1872) through the period of Porfiriato (i.e. the presidency of Porfirio Díaz, 1877-1910), education played a key role and its reform acquired great importance, as the purpose was to restructure and modernise it on the basis of the objective teaching of sciences, which was believed would drive the main transformations that the country needed in different sectors such as industry and public health. Intellectual education and science teaching were fundamental instruments that would be used to educate Mexican citizens and shape their sense of awareness.

Leoncio López Ocon Cabrera [1998] used the term "mensajeros de la ciencia" (science communicators) to refer to those who disseminated scientific content, stating that they were scientists, scholars and technicians in different branches of science. According to Cabrera [1998]:

"fueron cinco fundamentalmente los instrumentos usados por esos mensajeros para llevar a cabo su programa de aculturación científica: el uso de la prensa, la creación de un associacionismo científico y de nuevas instituciones 
educativas, la fundación de museos de historia natural y la participación en las exposiciones universales. Debido a su carácter portátil y a su capacidad de desplazamiento por el espacio y por el tiempo, quizás quepa considerar a los medios impresos como los que tuvieron mayor impacto en la creación de un interés social por el desenvolvimiento científico- técnico" [Cabrera, 1998, p. 205-225].

According to Bernadette Bensaude-Vincent [1993], in the 19th century, when the term "vulgarisation" (popularization) was created, hundreds of books, magazines and other publications focused on placing science within everyone's reach, by making full use of all the dissemination channels, such as courses, conferences, magazines, books, encyclopaedias, expositions and museums. Science was being adapted to all tastes and conditions, in a way that was "pratique, utile, amusante, récréative, populaire, mondaine, foraine. . . elle est dispense aux industriels, aux agriculteurs, aux dames, aux enfants, aux gens du monde" [Bensaude-Vincent, 1993, p. 49].

Bensaude-Vincent said there were different categories of science communicators who differred in the type of popularisation; some disseminated what was new from the scientific world, others supported popular science and believed that the aim was to promote the scientific culture in all layers of society by allowing everybody to access the most advanced knowledge and do amateur research.

Through their conferences and publications, science communicators aimed at communicating their knowledge to the general public, aiming at the population as a whole and giving priority to the working class and children. Within this context, science popularisation was regarded as a democratic concept of knowledge, of science for all, and according to many of these scientists science was the instrument to know the new nations that were being formed or consolidated at the time, in order to educate the population.

In this context, journalism embraced expressive writing, acquired a wide range of themes and readers, reached out to all social groups and encouraged reading. Several magazines and periodical publications included well-definied and specialised themes, some of which targeted a selected audience, others were intended for an intellectual elite, and others targeted the remaining sectors in society, including workers and children. There was an interest for literature, political, scientific, practical and useful topics.

Periodical literature publications for children played an important role in science popularisation, making innumerous scientific topics more child-friendly. These publications aimed at communicating science to the population as a whole, giving priority to the working class and children.

According to Consuelo Cuevas Cardona [2002], since the first half of the 19th century Mexico had seen the publication of magazines whose editors were already interested in disseminating scientific content. A few examples of such magazines were Registro Trimeste o Colección de memorias de historia, literatura, ciencias y artes (1832-1833), Revista Mexicana. Periódico científico y literario (1835-1836), Revista Científica y Literaria de México (1845), and La Ciencia Recreativa (1871-1879). 
Among these Mexican magazines, it is worth highlighting La Ciencia Recreativa, publicación dedicada a los niños y a las clases trabajadoras, which was edited in Mexico from 1871 and 1879 by José Joaquín Arriaga (1831-1896), a topographer and surveyor. This publication included content from different subjects such as cosmography, mineralogy, meteorology, physics, experimental physics, physics of the earth, botany, zoology, descriptive geography, industrial agriculture and the teaching of practical manufacturing.

Education and science in Mexico in the 19th century
In January 1958, Benito Juárez became the President of Mexico and tried to reorganise the country's administrative and educational sectors. In 1861, the Ministerio de Justicia, Fomento e Instrucción Pública (Ministry of Justice, Development and Public Education) was set up and the following year saw the development of Secretaría de Estado y Despacho de Justicia y Instrucción Pública. After the end of the French Intervention, during the Restored Republic (1867-1877) and the presidency of Benito Juárez, a peace-keeping and country reorganisation process began, with the ruling liberals wanting to establish a political agreement with the different sectors of society. The project of re-organisation of the country required a guarantee of peace among society and both science and education were important instruments to this aim.

On 15th July 1867, a commission was set up to study and put forward a proposal for the creation of a programme about public education and the promotion of science under the guidance of the then Minister of Justice and Public Education, Antonio Martínez de Castro. Among the members of this commission were Francisco and José Díaz Covarrubias, Pedro Contreras Elizalde, Ignacio Alvarado and Eulálio María Ortega, with doctor Gabino Barreda (1818-1881) as its president. Its work contributed to the writing of Ley Orgánica de Instrucción Pública (Public Education Law) on 2 December 1867.

In this context, Beatriz Zepeda stated that "para la élite liberal de la Reforma y la República Restaurada, la educación fue una panacea: era el instrumento mediante el cual se crearían los ciudadanos y se les imbuiría el orgullo de las instituciones republicanas de México y el amor a una patria cuyas raíces se remontaban a tiempos prehispánicos" [Zepeda, 2012, p. 183].

The education reform introduced during the Restored Republic aimed at restructuring and modernising the Mexican educational system, based on the objective teaching of sciences, which were regarded as the driving force behind the change needed in various sectors such as industry and public health. In order to implement this reform, Benito Juárez issued the decree Ley Orgánica de la Instrucción Pública no Distrito Federal in 1867.

According to the regulations proposed by the Ley Orgánica in 1867, primary education in the Federal District and in the territory of Baja California (Lower California) would be free for the poor and compulsory, the study of religion would no longer be available, a National Preparatory High School would be set up with one bachelor degree for all professional careers. Besides, there would be secondary schools for girls, other schools would be specialised in law, medicine, agriculture and veterinary science, engineering, natural sciences, arts, music and recitation, business and trade, high school teacher training, arts and crafts, and for deaf 
people. Finally, the National Astronomical Observatory and the National Academy of Science, Literature and Botanical Garden would be founded, and the National Library would be reorganised.

Both education and science often appeared in the proposals as well as in the speeches of different political groups as key factors in the national project for progress. During the Second Congress of Public Education held in 1891, Justo Sierra (1848-1912) — writer, politician and Minister of Public Education and Arts - declared that "hacer de la ciencia la sustancia de la enseñanza era cosa indiscutible en una época en que el fenómeno social característico es la ciencia, factor primero de la potencia material y espiritual de los pueblos [... ]" [Sierra, 1891, p. 468].

Hebe Vessuri highlited that during the last decades of the 19th century the recently formed Latin American nations saw a process of social and political transformations that led to the change in the established world of science, attributing importance to positive science [Vessuri, 1996]. The European positivism gave Latin American intellectuals and politicians a conceptual framework where to place history and society within the boundary of progress.

In this regard, it is worth emphasising the important role played by institutions such as Sociedad Médica de México (1865), Observatorio Astronómico Nacional (1863), Escuela Nacional Preparatoria (1867), Sociedad Mexicana de Historia Natural (1868), Sociedad Farmacéutica (1879), Academia Nacional de Medicina (1873), Comisión Geográfica Exploradora (1877), Sociedad Científica Antonio Alzate (1884), Sociedad Alejandro de Humboldt, Sociedad de Medicina Interna, Comisión Geológica (1886), Academia de Ciencias Exactas, Físicas y Naturales, Instituto Médico Nacional (1888), Instituto Geológico (1891), Escuela Nacional de Medicina, and Instituto Patológico Nacional (1901).

Within the movement of scientism in the 19th century it was not only a question of relying on knowledge, but also a matter of deriving the aims and values from knowledge itself. In this context, science became the centre of the universe, which forced liberalism to redefine its own terms, to abandon natural law and seek scientific grounds for its doctrine.

Science became the model, and the phylosophy that presented this ideal well was August Comte's positivism. With the Lei dos Três Estados (Law of Three States), Comte proposed to classify the history of mankind in different states, sorted by either chronological, theological, metaphysical and or positive order. Sciences would become positive, ranking from the simplest to the most complex one, from the most observed ones to the most tangible ones: positive sciences would be sorted by appearance, from mathematics to sociology, including astronomy, physics, chemistry and biology.

The National Preparatory School, founded in 1867, considered including in its courses the group of positive sciences, with one curriculum of disciplines for all its pupils organised according to the science classification put forward by Comte, with disciplines ranking from the simplest one to the most complex one.

Following the statement of Salvador Moreno y Kalbtk [2001] positivism included a theory of science and a reform of society at the same time, which was a way to 
organise society. Within this context, the principles of positivism were introduced with the aim of organising public education, to achieve a social order which was crucial for the country to progress. In 1879, with the Reglamento de las Escuelas Primarias Nacionales (national primary schools regulation), Protasio P. de Tagle, Secretary of Justice and Public Education, established the principle of useful teaching whereby new practices such as "Lecciones de cosas" (lessons on things) were to be introduced.

In 19th-century Mexico, within the context of the liberal project, science was subject to liberal education. The teaching of scientific topics was prioritised mainly because it could discipline minds. In this sense, learning physics or mathematics was not specifically aimed at educating scientists or engineers, but it was aimed at getting a solid educational foundation.

During the government of Porfírio Díaz, the Mexican modern school was based on moral, physical, intellectual and aestethical development of children and youth. It was to infuse into children the love for their home country, for order, progress and science, to create hard-working and progressist Mexicans, fond of their country and order. Mílada Bazant [2006] states that from the very beginning of the period of Porfiriato, physical and natural sciences were taught using the method named as lições das coisas (lessons on things) or ensino intuitivo (intuitive teaching) or objetivo (objective teaching). As highlighted by Bazant, within this context school classrooms saw the mistique aspect of progress. President Díaz supported high schools, particularly those specialised in agriculture and engineering, believing that the future of the country relied on the scientific education of agronomists and engineers.

Rodrigo Vega y Ortega [2012] described Mexico in 1870s: supremacy of the State over the Catholic Church, committment towards order and peace in society, development of communications and transport networks (rail, telegraph), reinforcement of the liberal project, adoption of positivism in scientific practice, and increase of profissionalisation of Mexican sciences, especially in the field of natural history.

According to Fefer [2001], the Restored Republic (1867-1877) and the government of Porfírio Diaz (1876-1910) were in favour of the growth, development and valorisation of sciences. Studies about the recognition of territory, exploration of natural resources and of those aimed to find a solution to the most critical problems of Mexican society, such as education and helth, received the attention of scientists. In this process, the State established solid alliances with the scientific communities, through the support of the government in the creation and development of scientific societies, research and teaching institutions.

José Joaquín

Arriaga a science communicator
José Joaquín Arriaga was born on 11 January 1831 in Puebla de los Ángeles, Mexico. He began his studies in the Lancasterian School "La Divina Providencia", led by José M. de la Veja, in Zacatlán de las Manzanas. He went back to Puebla where he was educated by private teachers including the Augustinian monk Frei José Roldán and continued his studies at Colegio Carolino, where he completed the course in phylosophy under the supervision of teachers such as José Mora y Daza, Teodosio Azeué and Juan Ortiz de Montellano. He then studied at Colegio de 
Minería, in Mexico City, where he obtained the diploma of topographical engineer and surveyor on 8 October 1859. After being awarded this qualification, he went back to Puebla, where he would carry out a considerable amount of topographical and hydrographical work. In 1863, he was appointed Subsecretário de Fomento (Undersecreatry of Development) by José Salazar Ilarregui, who was the railway manager between Puebla and Perote. Along this long route he supervised works such as the roads of Tepachero, San Diego, Alamos, the construction of masonry structures between the watch-towers of Puebla, and the reconstruction of the bridges of Noche Buena, Alzaseca, Amalucan, San Juan, San Cristóbal del Sabino and of Ocotes. On 21 July 1865 he received the Diploma Correspondente and a Communication of the Development Minister, Luis Robles Pezuela, as a recognition for his services. He was then appointed Inspetor Geral do Centro (General Surveyor) of Puebla (1865), becoming responsible for the inspection of roads from Puebla to Mexico City, to Perote and to Matamoros Izúcar, and from Tehuacán to Oaxaca.

He then went back to Mexico City and started a vibrant activity in journalism, founding the religious magazine La Revista Universal in August 1867, for which he worked as chief editor till mid-1869. At the end of 1868, together with Manuel María Villada, zoology expert for the Escuela de Agricultura (School of Agriculture), Antonio Peñafiel y Barranco, zoology expert for the Museo Nacional (National Museum), and Jesús Sánchez, he took part in the Scientific Commission which was in charge of exploring the territories around Tuyahualco, which, during that period, was referred to as "Pompeya Mexicana" (Mexican Pompeii), where the ruins of an ancient civilazation had been discovered.

In 1876, he took over as head of Hacienda de Querétaro in the state of Michoacan, where he moved with his family. He went back to Mexico City in May 1882, and in August he was appointed as Interim Director of the National School of Agriculture and Veterinary Science. He kept his post until April 1884. He worked as a topography teacher for this institution for a number of years.

Arriaga was a journalist who founded, led and collaborated with different magazines such as La Revista Universal (1867), El Defensor Católico (1872), El Tiempo (1883), El Nacional (1884), which at that time was led by Manuel Díaz de la Vega, and the Boletin de la Sociedad Agrícola Mexicana. He excelled as a collaborator and editor of religious periodicals, such as El Pueblo. Periódico de religión, literatura, ciencias, artes y noticias (1870), later denominated La Voz de México. Diario político, religioso, científico y literário de la Sociedad Católica, managed by Sociedad Catolica, created in 1863 and of which he was a member. This magazine was launched on 17 April 1870 and printed by Imprenta de Ignacio Escalante y Cia. He was also a member of the association Apostolado de la Cruz, founded in March 1896, and editor and writer for the publication Semanario Católico, which was a body of this institution.

He was one of the editors of the magazine El Minero Mexicano, dedicated to minerary, metallurgy and engineering, founded in 1873 by Mauricio Levek and edited by Sociedad Minera Mexicana. Arriaga was invited to lead this newly launched magazine where he became chief editor:

“dió á conocer su programa, en el que haciendo una perfecta sinopses de nuestra Minería en su conjunto y en sus relaciones con los diversos ramos que la constituyen ó la favorecen, expone sus exigencias y los medios de llenarlas; 
sus ventajas y la manera de obtenerlas; las dificultades que entorpecen su desarrollo y los elementos de que se puede disponer para destruirlas; el papel que desempeña y la influencia que ejerce en nuestro progreso intelectual y material como ciencia y como industria, desprendiendo de estas oportunas y sensatas reflexiones, la misión que corresponde llenar á un periódico minero, concibe y desde ese número comienza á desarrollar un plan perfectamente concebido, que revela que le era igualmente familiar el periodismo científico" Ramirez [1900, p. 27-28].

On 29 August 1868, he founded the Sociedad Mexicana de Historia Natural (Mexican Society of Natural History) jointly with Antonio del Castillo (1820-1895), Francisco Cordero y Hoyos (1826-1879), Alfonso Herrera (1838-1901), Gumesindo Mendoza (1829-1883), Antonio Peñafiel (1834-1922), Manuel Río de la Loza (1807-1876), Jesús Sánchez (1842-1911), Manuel Urbina (1843-1906) and Manuel María Villada (1841-1924). The objectives of this association were to know the natural history of Mexico, develop the study of all its branches and applications, gather and publish the work of national and international teachers on local products and create collections from the three kingdoms of nature. Arriaga, therefore, linked the study of natural sciences with his profession, publishing articles in La Naturaleza magazine, body of the Sociedad Mexicana de Historia Natural. Within this association he also became Primeiro Secretário (First Secretary) (1869). For this association he also worked as a numerary member as well as a Primeiro Secretário (First Secreatary), chief editor of the Comisión de Publicaciones (Publication Commission) (1870) and editor of its magazine, La Naturaleza. Periódico científico de la Sociedad Mexicana de Historia Natural (Nature. Scientific Periodical of the Mexican Society of Natural History).

He participated in various Mexican and international scientific associations. He became a corresponding member (1874) of the Academy of Natural Sciences of Philadelphia and a resident member (1869) of Sociedad Humboldt, founded in 1861 in Mexico City thanks to the initiative of the engineering students of Colegio de Minería, who had participated in the Comisión Científica del Valle de México (Scientific Commission of Valle de México) in 1855. He became a resident member (15/02/1868) of the Compañia Lancasteriana de México (Mexican Lancasterian Association), founded in 1822 and a honorary member (23/05/1871) of the Sociedad Mexicana de Geografía y Estadística (Mexican Society of Geography and Statistics), founded in 1833. Since 17 October 1873 he had been a member of the Sociedad Minera Mexicana (Mexican Mining Society), set up in 1873, the president (1883) of the Comision de Publicaciones (Commission of Publications) of this society, and fellow (26/12/1886) of the Unión IberoAmericana (Ibero-american Union), founded in 1885 in Spain.

On 23 March 1892, he was appointed as a member of the Instituto Médico Nacional (National Medical Institue), which had been founded in 1890 with the aim to study the flora, fauna, the national climate, medical geography and its applications. He collaborated with the publication Anales del Instituto Médico Nacional (Annals of the National Medical Institue). On 30 December 1895, he was awarded the diploma of Acadêmico Numerário. In 1892, he was appointed as a member of the Comisión de Enseñanza do Congreso Nacional Agrícola (Education Commission of the National Agriculture Congress). He died in Mexico City on 10 September 1896. 
Publications:

- Plano topográfico de la ciudad y alrededores de Puebla, en el sitio establecido por las tropas francesas, en los meses de marzo, abril y mayo / levantado por el Ingeniero José Joaquín Arriaga. [México] Litog. de O’Farrill, 1863.

- El microscopio y la fotografía aplicados al estudio de las ciencias naturales. Memoria leida por el Socio de Numero, Ingeniero Don Jose Joaquín Arriaga en la sesión del dia 8 de febrero de 1869. La Naturaleza. Periódico científico de la Sociedad Mexicana de Historia Natural. México, 1, p. 27-36, 1869.

- La ciencia recreativa: publicación dedicada a los niños y a las clases trabajadoras / dirigida por José Joaquín Arriaga. México: Imprenta de J. M. Aguilar Ortiz, 1871.

- El aerolito de Charcas. El Siglo Diez y Nueve, [México] 26 sep. de 1872, p. 3.

- Explotación de la ulla. El Minero Mexicano, México, tomo I, núm. 27, 1873-1874.

- Compañías Mineras. El Minero Mexicano, México, tomo I, núm. 30, 1873-1874.

- Informe que de los exámenes celebrados en la Escuela N. de Agricultura y Veterinaria en el año escolar de 1883, rinde al señor Ministro de Fomento/el director de dicha escuela. México: Imprenta de la Secretaria de Fomento, 1883.

- Arriaga, José Joaquín; Aguilar, Rafael; Puga, Guillermo B. (3 et 29 mai 1887) Les tremblements de terre du Mexique, 3 et 29 Mai 1887. La Nature. Revue des Sciences et de leurs applications aux arts et a l'industrie, Paris, Quinzième année, deuxième semestre, p. 182-183, 198.

- Nociones elementales de taqueometría é instrucciones para la práctica de la nivelación topográfica por el sistema americano. [Apendice] Diaz Covarrubias, Francisco. Tratado elemental de topografía, geodesia y astronomía práctica. México: Secretaría de Fomento, 1896.

19th-century journalism in Mexico City
During the second half of the 19th century in Mexico, there were 665 different periodical magazines, including literary, scientific, children, commercial and international ones. During the period of Porfiriato, in general, topics were well-defined, often targeting intellectual and professional elites, sometimes aiming at a growing middle class interested in topics about different subjects, such as literature, politics and science. This type of journalism also wanted to meet the needs of other, more popular, sectors, interested in practical and useful information.

Despite this variety of profiles, it is worth highlighting that the scientific magazines were the larger group. During the period of Porfiriato, science was a key priority and scientific literature found the right environment to thrive. The tipography of the Secretariat of Development itself supported more the publication of scientific journals as compared to literary ones.

During this period, the scientific scenario developed into an expressive form of journalism, through different publications, many of which wanted to disseminate scientific knowledge to the general public. Abigail Cruz Uribe stresses that, in this 
way, journalism stopped being an individual initiative to become an "aventura pública" (public adventure) [Uribe, 2011, p. 34].

According to Claudia Agostoni [2005], in the 1870s, children magazines that reached a broader public were: El Obrero del Porvenir (1870); La Enseñanza (1870-1876); El Correo de los Niños (1872-1883); El Escolar (1872); La Edad Feliz (1873); La Niñez Ilustrada (1873-1875); La Ciencia Recreativa (1873-1879); Los Chiquitines (1874); la Biblioteca de los Niños (1874-1876); and La Edad Feliz (1876).

Children magazines presented a variety of topics, such as scientific knowledge (agriculture, hygiene, mathematics, natural history, grography, etc.), religion, costumes and morality, pedagogical advice, gymnastics, industrial craft, history, literature, good citizenship and the biographies of important people. According to Rodrigo Veja y Ortega, the publication of these magazines, which increased in the 1870s, promoted informal education because "formaron parte de los recursos didácticos que los niños y niñas pertenecientes a las clases media y alta del país tuvieron para acercarse de forma amena a la ciencia ortodoxa, como fue la geografía" [Vega y Ortega, 2011a, p. 263].

Vega y Ortega [2013b] highlights that the magazines printed in Mexico City between 1835 and 1855 had among their editors and writers science experts and amateurs who were interested in scientific disciplines. Although the language used in these magazines was easy to understand and pleasant for their readers, it still promoted their education.

\section{La Ciencia}

Recreativa and natural history
On 2nd April 1871, the publication of La Ciencia Recreativa, publicación dedicada a los niños y a las clases trabajadoras was announced - a magazine designed and published by the enginner José Joaquín Arriaga, who described it as:

\begin{abstract}
"La obra anunciada tiene por fin generalizar los conocimientos científicos, embelleciéndolos con el artificio de la novela y por consiguiente, la nueva publicación arrojará las primeras semillas de este interesante estudio, que será muy fecundo en resultados para la generación que nos remplaza". [Apud. Un divulgador poblano en el siglo XIX, 2016].
\end{abstract}

In a letter that he sent to José María Ariza y Huerta, on 26th November 1871, Arriaga stated that he aimed to improve working classes, because "deseo que me anima de presentar a las clases pobres, nuevas fuentes de trabajo que mejoren su tristísima y angustiosa situación..." [Apud. Un Científico Poblano Olvidado, 2016].

José Joaquín Arriaga realised that, considering the purpose of the publication, which was the popularisation of knowledge for children and workers, it was important to adopt an adequate model for the published texts: fiction or, to put it in his words, "novelita" (story):

"El artificio de la novela se ha apoderado ya de la historia para hacer agradable su estudio. Prueba de ello es la aceptación que han encontrado en las masas las numerosas ediciones que se hacen día a día de tantas novelas históricas de los célebres novelistas franceses, que con el recurso de su pura imaginación han 


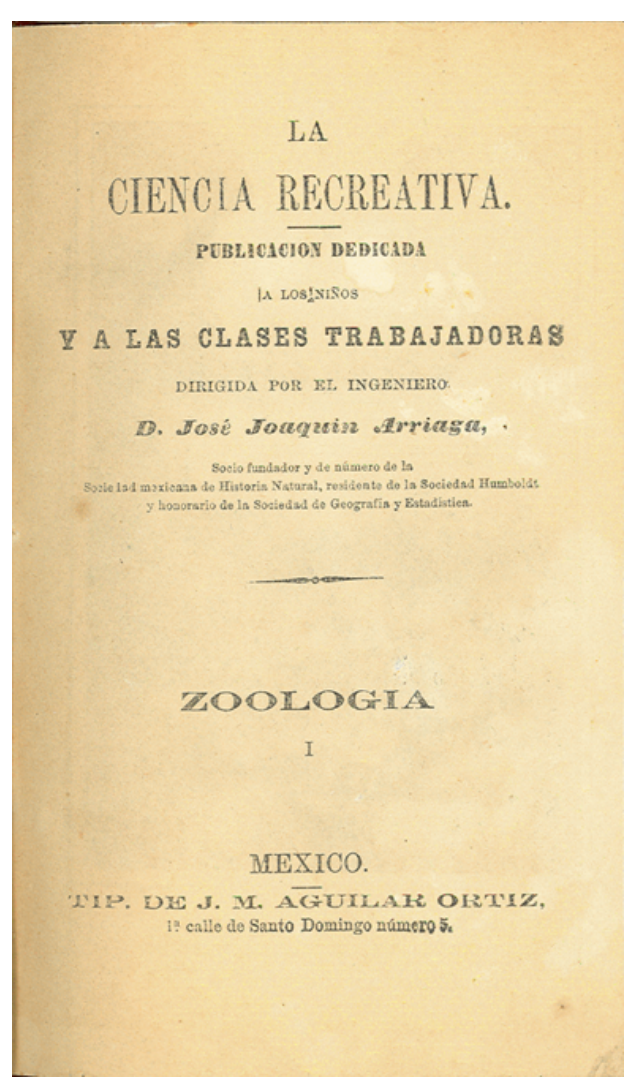

Figure 1. La Ciencia Recreativa. 1871.

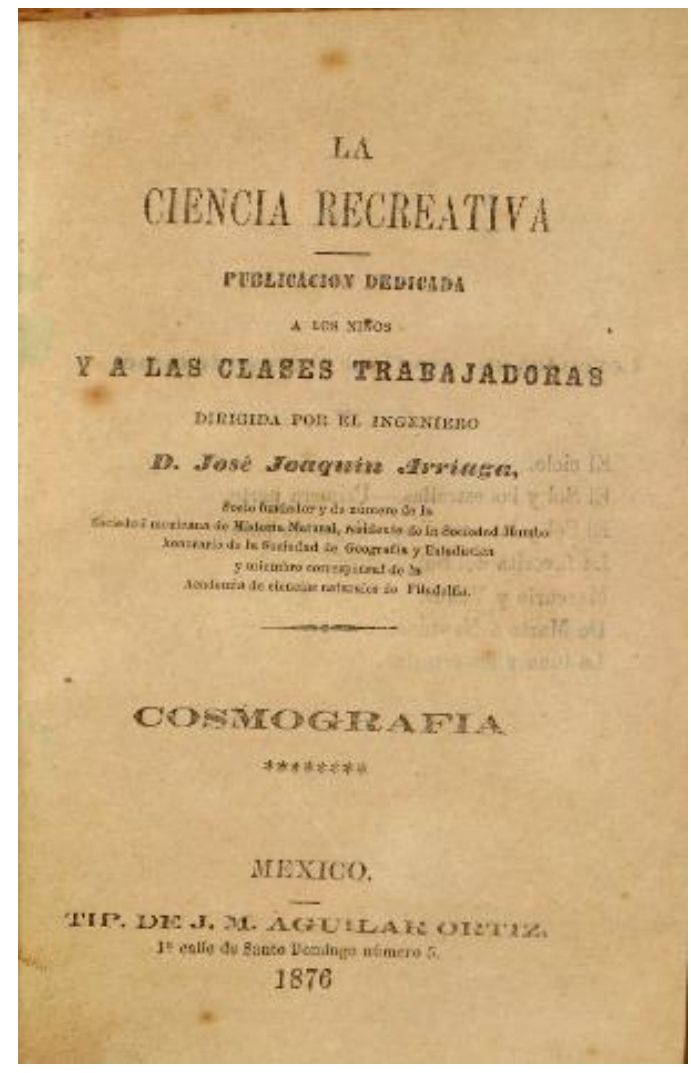

Figure 2. La Ciencia Recreativa. 1876.

cubierto de flores la áspera senda del estudio de la historia, gracias a ello, los principales episodios de la historia francesa son más conocidos en México que nuestra historia misma. La ciencia más ardua aún para los que no la aman por vocación, permanece desconocida entre nosotros y la mayoría de los mexicanos la ven con indiferencia, si no con el desprecio propio de la ignorancia, preciso es confesarlo. (...). La obra anunciada tiene por fin generalizar los conocimientos científicos, embelleciéndolos con el artificio de la novela y por consiguiente, la nueva publicación arrojará las primeras semillas de este interesante estudio, que será muy fecundo en resultados para la generación que nos reerriplaza". [Joaquin Arriaga, 1871, Apud. Un CientíficoPoblano Olvidado].

The books of La Ciencia Recreativa, made up of 36 to 40 pages each, were first published on 13 April 1871, and included various scientific topics. Each publication was divided into booklets, each one including a litography by Hesiquio Iriarte $y$ Zuñiga (1824-1903), or a drawing done by José María Velasco (1840-1912), or litographies by Viuda de Murguía y Hijos.

The publications had four seasons, with 18 issues in the first, 24 in the second, 22 in the third and 19 in the fourth. It was a bi-weekly or monthly magazine, available on 12th and 26th of each month. The content of the overall work made up of 12 volumes, was divided into two series and three seasons. The topics available in the booklets had the following titles: cosmography, mineralogy, meteorology, physics, experimental physics, physics of the earth, botany, zoology, descriptive geography, industrial farming and practical manufacturing. Its "novelitas" (stories) had a subindex, which showed which chapters the topics were divided into, and at the 


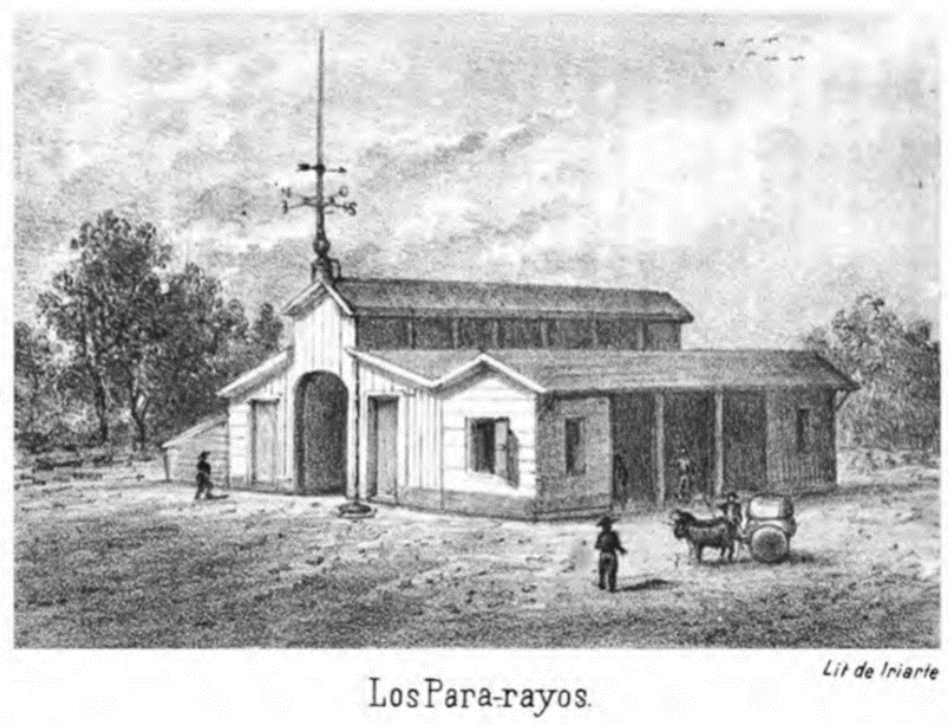

Figure 3. Los Para-rayos. 1871. Litography by Hesiquio Iriarte y Zuñiga (1824-1903).

end of the volume there was a glossary with the terminology that appeared in the text. Ninty books were published in La Ciencia Recreativa (see appendix), among which it is worth mentioning Física del Globo. Pluton y Neptuno (1871), Agricultura. Historia de un grano de café (1871), La vida de las flores. Botánica. Principios de organografía y de fisiología vegetal (1871), Cosmografía. Los planetas. Mercurio y Venus (1872), Meteorología. El barómetro y el termómetro (1873), Física-Optica. Espectros y fantasmas (1874), Cosmografía. El Sol y las estrellas (1874), Mineralogía (1876), Física experimental. Tomo II (1877), Zoología-Entomología: Un viaje al país de las Larvas (1879), Agricultura e Industria (1879).

La Ciencia Recreativa paved the way for a scientific children's press, which at that time dealt with religious teaching, recreation for minors (divinations, poems, stories) and some scientific articles. It was recognised that it was one of the first scientific publications focused on children according to the Mexican press and the Sunday magazine El Ferrocarril:

\footnotetext{
“Embellecidas con los rasgos brillantes y pulidos de José Joaquín Arriaga, adornado con el pincel de su fantasía, con la ternura del poeta nos ofrece poner la ciencia bajo la mirada del hijo del pueblo, del que no ha cursado las aulas, del que sabe sentir y llorar sin haber estudiado en otro libro que en su corazón. La Ciencia Recreativa va a infundir en los niños el amor al estudio, va a descorrer en los jóvenes el velo misterioso de la naturaleza. Esa publicación será más que un libro, será una lámpara que arrojando su apacible luz en la cámara oscura de mil imaginaciones haga reverberar después de ellas la irradiante luz que ilumina el pensamiento de los que han comprendido toda la grandeza que encuentran las creaciones de Dios". [Apud. Uribe, 2011, p. 35].
}

Other publications also commented on La Ciencia Recreativa, such as El Católico of Zacatecas, which appraised Arriaga's initiative, La Sombra de Arteaga, official 
magazine of the State of Querétaro, which reccommended La Ciencia Recreativa for its usefulness and accessible price, El Siglo XIX, which highlighted how it made the study of science more appealing thanks to its stories, and La Oposición, which emphasised Arriaga's contribution to journalism, although it did not share his political views [Uribe, 2011].

Abigail Cruz Uribe [2011] highlights that in La Ciencia Recreativa there was a scientist preoccupied with science, morality, good practices and the country. As he was originally from Puebla, when dealing with "La Porcelana" (porcelain), Arriaga presented a legend of the "Alto" neighbourhood in Puebla, which described it as being highly populated, with its streets, its buildings being destroyed and uninhabited, where there was a fertile territory for the development of its walls made of adobe.

The law of 1867 followed up the social reform proposed by the government of Juárez and was especially based on the acquisition of scientific knowledge that enabled the development of economic and social activities of the Mexican population. It had set up a curriculum for primary education of boys, with subjects such as "Lectura y Escritura, Gramática castellana, Estilo epistolar, Urbanidad, Dibujo lineal, Moral, Aritmética, Sistema métrico decimal, Elementos de Física, Artes, Fundamentos de Química y Mecánica prácticas, Nociones de Derecho y Rudimentos de Historia y Geografía con énfasis en México" [Vega y Ortega, 2012].

Besides, through the decree of 14 January 1869, Juarez expressed his interest for the development of science in the country, emphasising different aspects of public education, such as the importance of freedom of teaching, the need to disseminate and communicate exact and natural sciences, and the establishment of Escuela de Naturalistas (School of Naturalists). These objectives were based on positivism disseminated by Gabino Barreda, in the Escuela Nacional Preparatoria (Preparatory National School) and on lay, encyclopaedic and pragmatic precepts, that would communicate to students of any discipline what was referred to as scientific truths [Vega y Ortega, 2012].

Publications from the children's press, such as La Ciencia Recreativa, as well as the adult press, presented a variety of topics ranging from history, biographies, spelling and writing, texts with moral or religious content, tales, theatre, poems and stories, and the useful knowledge taken from science. The publication of Arriaga introduced the reader to scientific disciplines such as agriculture, anatomy, medicine, astronomy, natural history, arithmetics, chemistry, hygiene, physics, geography, and others.

Vega y Ortega [2012] highlights that objects of natural history were explained to the readers and natural history, at that time, was understood as:

"el estudio de dos tipos de seres: unos dotados de vida, que nacen y mueren después de crecer, y que tienen una forma determinada en su cuerpo tras la asimilación de nuevas moléculas con las que ocupan un lugar determinado en el mundo y, particularmente, cuentan con la facultad de perpetuarse por medio de gametos (células sexuales) que al desarrollarse siguen la misma forma, tales como animales, vegetales y microorganismos; y otros que no tienen vida y, por lo tanto, no mueren y corresponden a los minerales". [Vega y Ortega, 2012, p. 341-342] 
The dissemination of natural history was given a major role both in Mexican magazines targeting general public, and in those dedicated to specific sectors in society whether they targeted certain age, gender, or professional groups (for example, craftsman). The naturalist knowledge available in publications such as $L a$ Ciencia Recreativa was for workers one of the resources they could access to obtain information about scientific topics that they came across in their job.

The knowledge of natural history disseminated in these publications was not the same for all readers, as the specific needs of each group were addressed. Besides, Veja y Ortega highlights that the interest of each group of readers was dictated by the editors of each journal. These editors, from "República de las Letras", were scholars in various scientific, humanistic and artistic disciplines.

The dissemination of natural history knowledge was part of the efforts made to represent the natural wealth of the Mexican territory, which was necessary for the economic and political projects of Mexican society [Vega y Ortega, 2011b].

Rodrigo Vega y Ortega [2013a] emphasises that, considering the popularisation of sciences promoted by publications such as La Ciencia Recreativa, the education system formally set up by the Mexican State to learn science had put education aside and informal education took place privately. The schools and institutes dedicated to the first stage of literacy taught reading, writing, arithmetic, Christian and civil studies. In this way scientific knowledge was learnt outside the classroom with publications such as La Ciencia Recreativa. The projects for the popularisation of scientific knowledge were private and running in parallel with the state's efforts.

The 19th century saw the increase of periodical publications, with numerous magazines being launched not just for children but also for workers and women. Anne Staples highlights that this was triggered not only by the interests of intellectual people, but also by the emerging of technical innovations in the country, such as oil lamps, gas lamps and later electric lamps, facilitating the increase and dissemination of press [Staples, 1988. Apud. Galván, 1998].

As in the case of children, other social groups such as women, workers, farmers and craftsmen, acquired scientific knowledge informally, thanks to publications such as La Ciencia Recreativa. The publications aimed at science popularisation were primarily focused on disseminating science in a way that could be understood by everyone and applied by the whole population daily.

The role played by children's publications such as La Ciencia Recreativa in the dissemination of scientific knowledge was remarkable, as they made content available to all children. Besides educating and entertaining, these magazines were used by primary school teachers as additional resources. 
Table 1. La Ciencia Recreativa.

\begin{tabular}{|c|c|}
\hline Year & Title / Topic \\
\hline \multirow[t]{24}{*}{1871} & Física del Globo. Pluton y Neptuno \\
\hline & Introducción general. La primera semilla \\
\hline & Meteorología. Los misterios de la niebla \\
\hline & Meteorología. Las tempestades \\
\hline & Meteorología. El titan y el Pigmeo \\
\hline & Meteorología. El termómetro y el barómetro \\
\hline & Meteorología. Los prodigios (primera parte) \\
\hline & Meteorología. Los prodigios (segunda parte) \\
\hline & Agricultura. Historia de un grano de café \\
\hline & Geografía física del globo. Los campos de nieve \\
\hline & Física experimental y recreativa. Impresiones de viaje del Tio Pablo \\
\hline & Geografía física del globo. Pluton y Neptuno \\
\hline & Física. Transformaciones de un trozo de hielo \\
\hline & Meteorología. Las tempestades \\
\hline & Meteorología. El titan y el pigmeo \\
\hline & Física del globo. Los aerolitos \\
\hline & Agricultura e industria. Historia de un pan de azúcar \\
\hline & Zoología. Los operarios del mar \\
\hline & Zoología. Los jardines del océano. Primera parte \\
\hline & Zoología. Los jardines del océano. Segunda parte \\
\hline & Zoología. Malacología \\
\hline & Zoología. Los gigantes del océano \\
\hline & La vida de las flores. Botánica. Principios de organografía y de fisiología vegetal \\
\hline & Agricultura e industria I. \\
\hline \multirow[t]{10}{*}{1873} & Física. El telescopio y el microscopio \\
\hline & Zoologia. Tomo $2^{\circ}$. [1873 or 1879] \\
\hline & Zoología - Conchiologia. Nereidas y tritones \\
\hline & Mineralogía. Un héroe del mundo subterráneo \\
\hline & Botánica. Flores y fructos \\
\hline & Física del globo. Del Ecuador al Polo \\
\hline & Meteorología. El barómetro y el termómetro \\
\hline & Los jardines del oceano. Primera parte. Zoología. Zoofitología \\
\hline & Cosmografía. Los planetas. Mercurio y Venus \\
\hline & Física. Los prodigios del vapor \\
\hline \multirow[t]{14}{*}{1874} & Meteorología I \\
\hline & Geografía descriptiva. La vida polar \\
\hline & Cosmografía. La Favorita del Sol \\
\hline & Zoología. Los Gigantes del Oceano \\
\hline & Física - Optica. Espectros y fantasmas \\
\hline & Cosmografía. El cielo \\
\hline & Mineralogía. La hija del lapidario \\
\hline & Geografía descriptiva. El mar libre del Polo \\
\hline & Botánica. Los misterios de la Flor \\
\hline & Zoología - Entomología. Los Insectos \\
\hline & Agricultura e Industria. El cultivador del Maguey \\
\hline & Cosmografía. El Sol y las estrellas \\
\hline & Botánica. El polen, el ovulo y el grano \\
\hline & Geografía descriptiva. Los desiertos \\
\hline 1874 [or 1875] & Botánica. Las grandes familias vegetales \\
\hline \multirow[t]{2}{*}{1876} & Cosmografía \\
\hline & Mineralogía \\
\hline 1877 & Física experimental. Tomo II \\
\hline \multirow[t]{7}{*}{1879} & Zoología: Los insectos \\
\hline & Zoología - Entomología: Los fabricantes de seda \\
\hline & Zoología: Los reyes del aire \\
\hline & Zoología: Verdugos y Asesinos \\
\hline & Zoología: Panales y Colmenas \\
\hline & Zoología - Entomología: Un viaje al país de las Larvas \\
\hline & Agricultura e Industria \\
\hline
\end{tabular}


Agostoni, C. (2005). 'Divertir e instruir. Revistas infantiles del siglo XIX mexicano'. In: La republica de las letras: asomos a la cultura escrita del México decimonónico. Vol. II. Ed. by B. C. d. Lara and E. S. Guerra. México: UNAM, pp. 171-182.

Bazant, M. (1997). 'Lecturas del Porfiriato'. In: Historia de la lectura en México.

- (2006). Historia de la educación durante el porfiriato. México: El Colegio de México, Centro de Estudios Históricos.

- (2012). 'La Educación Moderna, 1867-1911'. In: Historia de la educación en la Ciudad de México. Ed. by P. G. Aizpuru and A. Staples. México: El Colegio de México, Centro de Estudios Históricos, Secretaría de Educación del Distrito Federal, pp. 245-327.

Beltrán, E. (2017). El primer centenario de la Sociedad Mexicana de Historia Natural (1868-1968).

Bensaude-Vincent, B. (1993). 'Un public pour la science: l'essor de la vulgarisation au XIXe siècle'. Réseaux 11 (58), pp. 47-66. DOI: 10.3406/reso.1993. 2304.

Cabrera, L. L. O. (1998). 'La formación de un espacio público para la ciencia en la América Latina del s. XIX’. Asclépio. Revista de Historia de la Medicina y de la Ciencia 50 (2), pp. 205-225.

Cardona, C. C. (2002). 'Historia y Divulgación de la Ciencia em México'. In: Antología de la divulgación de la ciencia en México. Ed. by J. T. Mazón, A. M. S. Mora and N. C. Arredondo. México: Dirección General de Divulgación de la Ciencia, UNAM, pp. 121-129.

Contreras, J. M. (2008). 'Una historia para una infancia. El discurso histórico en publicaciones periódicas infantiles de finales del siglo XIX en México'. Boletín del Instituto de Investigaciones Bibliográficas XIII (1-2), pp. 157-177.

Díaz y De Ovando, C. (1972). La Escuela nacional Preparatoria. Los afanes y los días 1867-1910. vol.I. México: Universidad Nacional Autónoma de México, Instituto de Investigaciones Estéticas.

Fefer, R. G. (2001). '(Presentación). La Biblioteca Botánico-Mexicana. Un artefacto de y para la ciencia nacional'. Relaciones. Estudios de Historia y Sociedad XXII (88), pp. 167-206.

Galván, L. (1998). 'El Álbum de los Niños. Un periódico infantil del siglo XIX'. Revista Mexicana de Investigación Educativa 3 (6, julio-dici).

Joaquin Arriaga, D. J. (1871). La Ciencia Recreativa. Introducción general. Publicación dedicada a los niños y a las clases trabajadoras dirigida por el ingeniero D. J. Joaquin Arriaga, socio fundador y de número de la Sociedad Mexicana de Historia Natural, residente de la Sociedad Humboldt y honorario de la Sociedad de Geografía y Estadística. México: Imprenta dirigida por Jose Batiza.

Moreno y Kalbtk, S. (2001). El Porfiriato. Primera Etapa (1876-1901). Ed. by F. Solana, R. C. Reyes and R. B. Martínez. México: FCE, pp. 41-82.

Ramirez, S. (1900). Estudio Biográfico del Sr. Ingeniero D. Jose Joaquin Arriaga, Académico numerario. Leido en la Academia Mexicana de Ciencias Exactas, Físicas y Naturales correspondiente de la Real de Madrid por el Ingeniero de minas Santiago Ramírez, académico de la misma clase en la sesión del 3 de julio de 1897. México: Oficina Tipográfica de la Secretaría de Fomento.

Romo, A. D. (2009). 'The Nation as a protagonist of education in Latinamerica (1870-1930)'. Revista Historia de la Educación Latinoamericana 14, pp. 239-266.

Sierra, J. (1891). ‘Organización de la enseñanza preparatoria'. In: Segundo Congreso de Instrucción Pública. Informes y Resoluciones. México: Imprenta de El Partido Liberal, pp. 468-474.

Uribe, A. C. (2011). ‘El Julio Verne de la ciencia mexicana, José Joaquín Arriaga, y la divulgación de la ciencia en la segunda mitad del siglo XIX'. Mixcoac de la academia a la sociedad. Preparatoria 8. Año 8.2 (24), pp. 34-38. 
Vega y Ortega, R. (2011a). "“Desde la margen del Bravo, hasta el valle donde se alza el Soconusco elevado": la geografía en las revistas para niños (la década de 1870)'. Antíteses 4 (7), pp. 247-266.

- (2011b). "Difundir la instrucción de una manera agradable": Historia natural y geografía en revistas femeninas de México, 1840-1855'. Revista mexicana de investigación educativa 16 (48), pp. 107-129.

- (2012). 'Los reinos de la naturaleza en la prensa infantil de México, 1870-1878'. Revista Brasileira de História da Ciência 5 (2). jul.-dez., pp. 336-353.

- (2013a). 'La zoología y el Diario de los niños (ciudad de México, 1839-1840)'. Revista Historia de la Educación Latinoamericana 15 (20), pp. 275-293.

- (2013b). 'Recreación e instrucción botánicas en las revistas de la ciudad de México, 1835-1855'. Historia Crítica 49, pp. 109-133.

Vessuri, H. (1996). 'La ciencia académica en América Latina en el siglo XX'. In: Historia Social de las Ciencias en América Latina. Ed. by J. J. Saldaña. México: Coordinación de Humanidades, Coordinación de la Investigación Científica/UNAM, pp. 437-479.

Zepeda, B. (2012). Enseñar la nación. La educación y la institucionalización de la idea de la nación en el México de la Reforma (1855-1876). México: Fondo de Cultura Económica, Conaculta.

Bachelor's and Bachelor's Degree in History awarded by the Pontifical Catholic University of Rio de Janeiro (1979). Master's degree in History from the Universidade Federal Fluminense (1986) with a dissertation entitled "Contestação e Defesa: A Congregação Beneditina Brasileira no Rio de Janeiro (1830-1870)". ["Dispute and Defense: The Brazilian Benedictine Congregation in Rio de Janeiro (1830-1870)"].

Ph.D. in Social History awarded by the University of São Paulo (1997) with a dissertation entitled "A única Ciência é a Pátria: o discurso científico na construção do Brasil e do México (1770-1815)" [The only Science is the Homeland: the scientific discourse in the construction of Brazil and Mexico (1770-1815)]. Current professional activity:

- Researcher at the Research Institute 'Casa de Oswaldo Cruz / Fundação Oswaldo Cruz' and Professor of the Postgraduate Programme in History of Science and Health (COC / Fiocruz).

- Coordination of the Historical-Biographical Dictionary of Health Sciences in Brazil (1832-1930). Available on the Internet: http://www.dichistoriasaude.coc.fiocruz.br - Coordination of the project "Ciência para todos: uma história da vulgarização científica entre os séculos XIX e XX no espaço ibero-americano" (PROEP / COC / $\mathrm{CNPq}$ ) ["Science for all: a history of the scientific vulgarisation between the $19^{\text {th }}$ and $20^{\text {th }}$ century in the Ibero-American space".

E-mail: rachelfroes2@gmail.com.

How to cite (c) $(1)$
Fróes da Fonseca, M. R. (2017). 'La Ciencia Recreativa and the popularisation of science in Mexico in the 19th century'. JCOM 16(03), A07_en. 